\title{
東北地方太平洋沖地震による石巻市桃生町の局所的な建物被害と微動 $\mathrm{H} / \mathrm{V}$
}

\author{
小田義也* · 戸田雄太朗*
}

\begin{abstract}
要 旨
2011 年 3 月 11 日に発生した 2011 年東北地方太平洋沖地震は, 巨大津波の発生を伴い, 関東か ら東北の沿岸部において甚大な津波被害をもたらした。その一方で地震動による被害は地震の規模や 震度に対して比較的小さかった。宮城県石巻市桃生町においても地域全体で見ると比較的被害は少な かったが，ごく限られた数力所で家屋の倒壊など深刻な被害が発生していた。この局所的な被害の原 因を探るため, 本研究では, 桃生町を南北に縦断する東浜街道沿い約 3.8 キロの範囲において建物の 被害調查と常時微動観測を行いそれらの比較を行った。被害調査の結果から各建物の被害程度を $\mathrm{A}$ か ら F まで 6 段階に分類したところ，310 棟のうち被害が深刻な A，B ランクの建物は 10 棟（約 $3 \% ）$ であった。そして, 深刻な被害は桃生総合支所周辺の数力所に限られていた。常時微動観測は調查範 囲内の 46 地点で実施した。微動 $\mathrm{H} / \mathrm{V}$ の卓越振動数は $1 \mathrm{~Hz}$ から $4 \mathrm{~Hz}$ 程度まで幅があったが，被害 ンク $\mathrm{A}, \mathrm{B}$ の地点では，微動 $\mathrm{H} / \mathrm{V}$ の卓越振動数が $2.5 \mathrm{~Hz}$ 以上であることが明らかになった。今回の地 震で観測された加速度記録の多くが $1 \mathrm{~Hz}$ 以上の短周期成分の卓越していたことから, $2.5 \mathrm{~Hz}$ 以上の卓 越振動数を持つ地盤において共振現象による増幅が生じた可能性が高い。ただし, 卓越振動数が $2.5 \mathrm{~Hz}$ 以上でも被害が小さい場合があるため今後詳細な検討が必要である。
\end{abstract}

キーワード : 2011 年東北地方太平洋沖地震 - 石巻市桃生町 ・ 局所的建物被害 ・微動 H/V ・ 共振現象

\section{1. はじめに}

2011 年 3 月 11 日に発生した東北地方太平洋沖地震は, 巨大津波の発生を伴い，関東から東北地方の太平洋沿岸 地域に甚大な津波被害をもたらした。その一方で，マグ ニチュード 9.0 という地震の規模や, 最大震度 7 を記録 しているにも関わらず，摇れ（地震動）による被害は比 較的小さかったと指摘されている。多くの観測記録にお いて 1 秒以下（1Hz 以上）の短周期が卓越し，建物の大 きな被害に結びつくといわれている 1 から 2 秒 $(0.5 \mathrm{~Hz}$ から $1 \mathrm{~Hz}$ ）の成分が大きくなかったことが原因であると いう見方が多い（例えば，飯塚ほか，2011）。著者らが 宮城県から岩手県にかけて実施した被害調查でも，地震 動による被害は，マグニチュード 9.0 という地震の規模 や各地の震度から予想されるものに比べ小さいという印
象を受けた。

しかし，このように市区町村レベルで評価すると被害 が比較的小さく見える場合でも，その地域の中を詳細に 調査すると局所的に深刻な被害が生じていることがある。 今回の地震において, 宮城県石巻市桃生町 (以下, 桃生 町）もそのようなケースであった。桃生町の本震震度は 6 強, 桃生総合支所管内の被害状況（2011 年 6 月 10 日 石巻市桃生総合支所内掲示）は, 全壊家屋が 28 棟, 半 壊家屋が 51 棟、ブロック塀倒壊が 74 カ所であった。桃 生町の中心部を南北に縦断する東浜街道沿いに被害状況 を概査すると，ごく限られた場所で深刻な被害が生じて いることがわかった。特に全壊家屋は数百メートルの範 囲に集中しており，地震による強い摇れが局所的に生じ ていたことを示唆していた。 
(a)

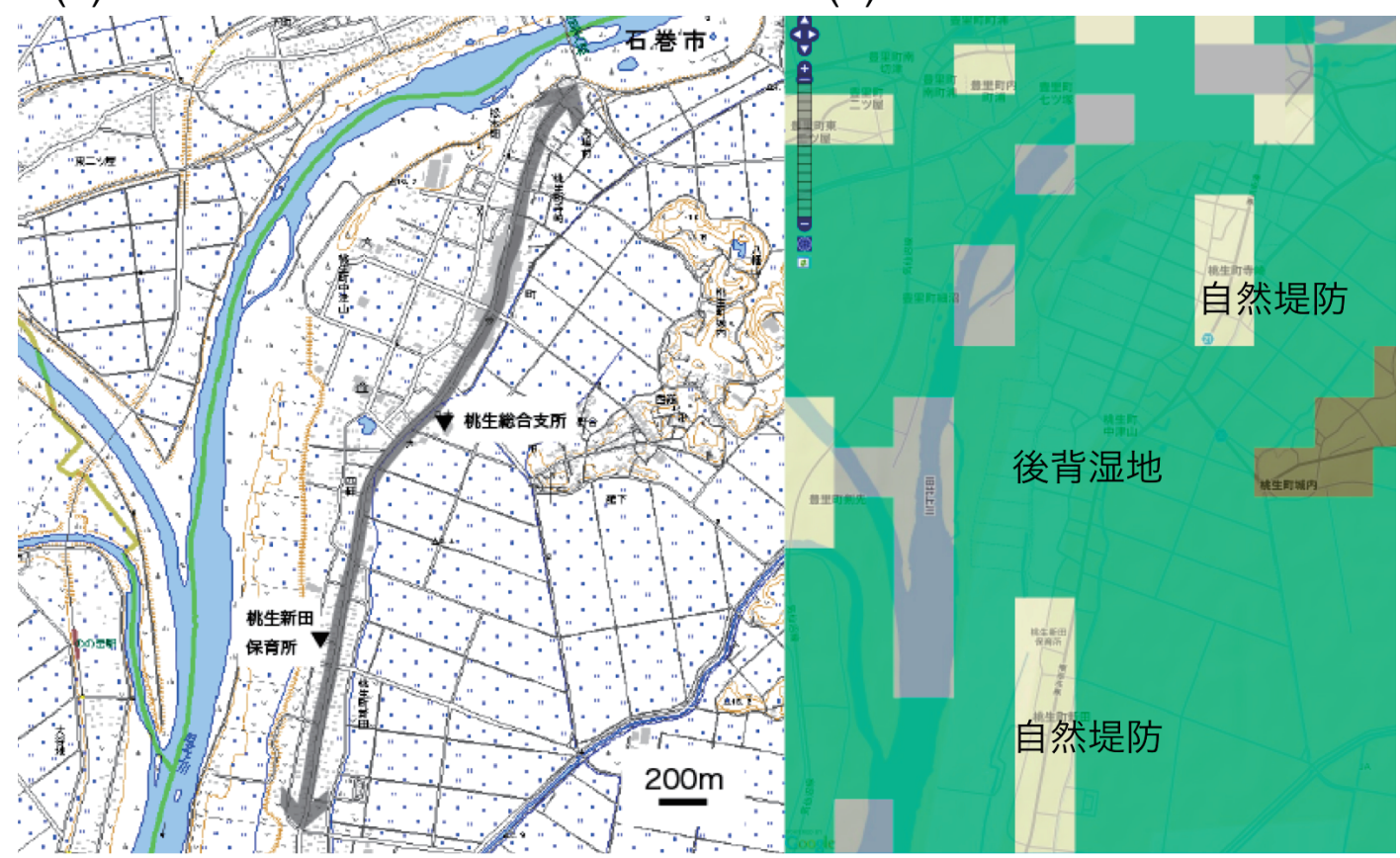

Fig. 1. Map of the study area. (a) The investigation of house damages and microtremor mesurements are conducted along the Higashihama Kaido street (gray arrow). (b) Geomorphological land classification map (http://www.j-shis.go.jp/) arround the observation area.

著者らは，この局所的な被害の発生メカニズムを解明 するため, 詳細な建物被害調査, 常時微動観測, そして, 強震動観測を実施することとした。現在も調査は継続中 であるが，本論では建物被害と常時微動観測から得られ る微動 $\mathrm{H} / \mathrm{V}$ の卓越振動数との関係についてケーススタ ディとして報告する。

\section{2. 石巻市桃生町}

石巻市桃生町（Fig.1a）は宮城県の北東部に位置し， 北上川と旧北上川に囲まれた地域であり，過去に何度も 洪水被害に見舞われているが，同時に肥沃な土地に恵ま れた地域でもある。町は南北に 13 キロメートル，東西 に 7 キロメートルで総面積は 43.82 平方キロメートルで, 丘陵地帯が $24 \%$, 農地（主に水田）が約 $48 \%$ を占めて いる。世帯数は約 2,300 , 人口は 8,000 人弱である。

桃生町を南北に走る東浜街道は，かつて仙台から気仙 沼を経て岩手県へとつながる街道であった気仙道の一部 である。今回調査を行った範囲内にある桃生町寺崎は, かつて北上川の舟運，そして，宿場として栄えた寺崎宿 があった場所でもある。洪水被害が顕著ではあるが，地 元の方によれば，この街道周辺は「地震の通り道」と呼 ばれることもあるそうで，昔から地震の際にはよく摇れ る地域であったことがうかがえる。調查を実施した東浜 街道沿いは地形的な起伏はあまりなく，桃生町寺崎から
高須賀までの住宅地から耕地は海抜 $2.4 \mathrm{~m}$ から $3.9 \mathrm{~m}$ と ほとんど平らといってよい状態である（桃生町史編纂委 員会, 1990)。また，250m メッシュ微地形区分（若松ほ か，2004）によれば，調査地域は主に後背湿地で，北側 と南側の一部が自然堤防に分類されている（Fig. 1b）。

\section{3. 建物被害調査}

\section{1 調査方法}

著者らは本震発生から約 1 ケ月後の 4 月 4 日に被苂地 において局所的な被害の存在を確認し，その後， 6 月 10 日から 12 日にかけて詳細な被害調査を実施した。本震 発生から 3 个月経過しているが, 現地の復旧作業は非常 に遅れており, 多くの建物は本震直後の状態が保たれて いた。調査範囲は，豊里大橋南詰から桃生町新田まで東 浜街道沿い約 $3.8 \mathrm{~km}$ の区間とした（Fig. 1a）。調査の方 法は，短期間で多くの建物の調査を行う必要があること から，比較的簡便かつ客観的に建物の被害を評価できる 八幡ほか（2008）の方法を採用した。この方法は，建物 の外観上の被害を目視で確認するもので，Fig. 2 に示寸 チェックシートを用いて調查を行う。調査項目は建物種 別に関するものと，被害に関するものに大きく分けられ ている。被害については,「全面つぶれている」,「外装が はがれている」，「ドア（空）が完全に閉まらない」など 客観的に判断できる 18 項目について該当するものす心゙ 


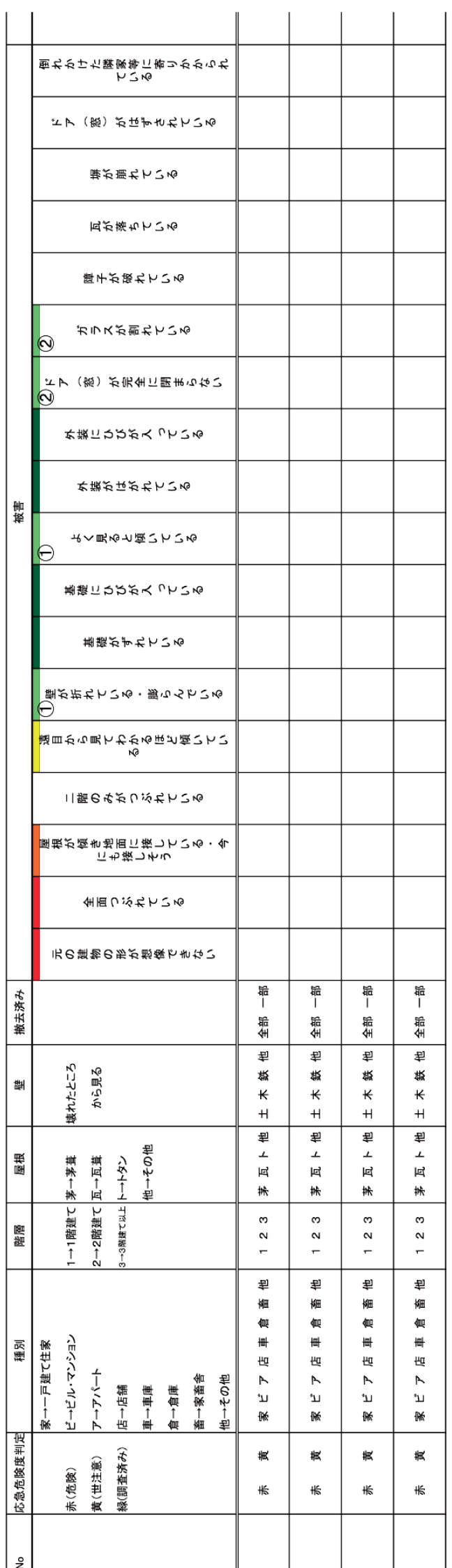
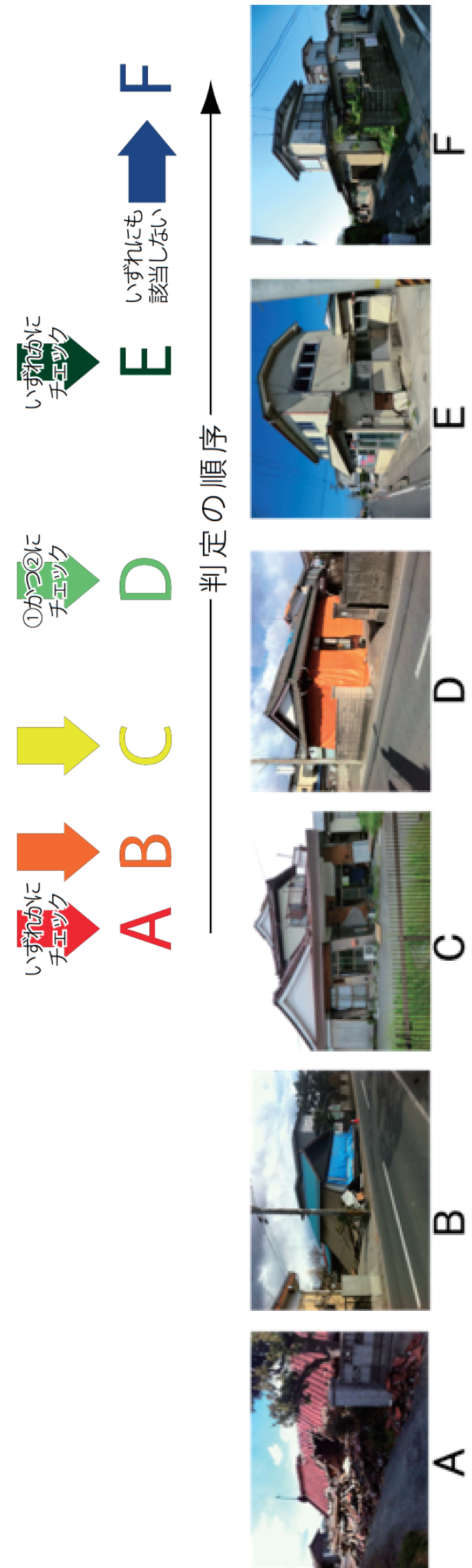

Fig. 2. A check sheet used in this study (Yahata et al., 2008) and examples of damaged house classified each damage rank. 


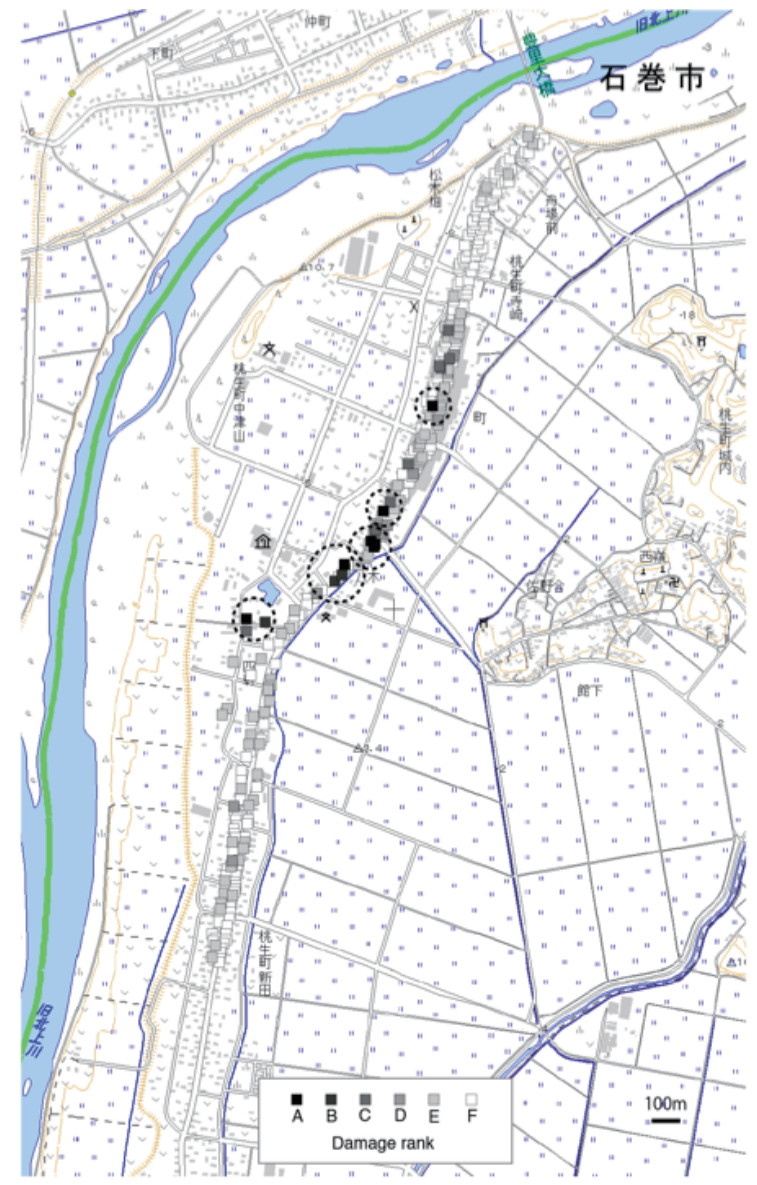

Fig. 3. Map view of distribution of damaged houses classified into $\mathrm{A}$ to $\mathrm{F}$ rank according to the investigation. Damaged houses classified as A or $\mathrm{B}$ rank locate in the confined area (dashed circles).

てにチェックを付ける。被害程度の評価は，このチェッ クシートをもとに最も被害の大きい $\mathrm{A}$ ランクから, 被害 の小さい F ランクまでの 6 段階で行う。なお，被害程度 の評価は建物の構造的な被害を対象としており，家具の 転倒など建物内部の被害は評価の対象としていない。

Fig. 2 には各ランクに該当する建物の例も合わせて示し た。

被害調查を実施した建物の総数は 310 棟で, 建物の用

Table 1. Results of the investigation of house damage.

\begin{tabular}{c|c|c} 
被害ランク & 軒数 & 割合 \\
\hline $\mathrm{A}$ & 7 & $2.26 \%$ \\
$\mathrm{~B}$ & 3 & $0.97 \%$ \\
$\mathrm{C}$ & 9 & $2.90 \%$ \\
$\mathrm{D}$ & 9 & $2.90 \%$ \\
$\mathrm{E}$ & 83 & $26.77 \%$ \\
$\mathrm{~F}$ & 199 & $64.19 \%$
\end{tabular}

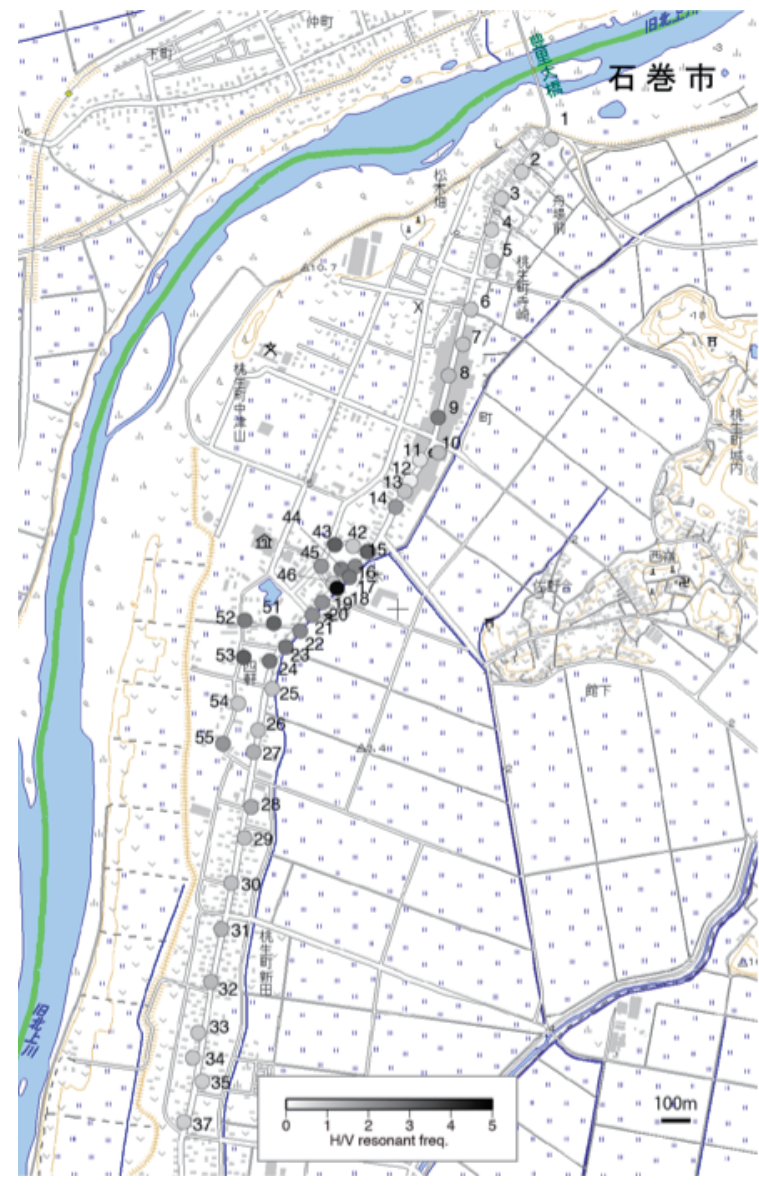

Fig. 4. Results of microtremor measurements. Circles show location of observation points and the color of symbols represents resonant frequency of $\mathrm{H} / \mathrm{V}$ spectrum ratio.
途は一般家屋が 211 棟 $(68 \%)$, 店舗等が 77 棟 $(25 \%)$, 車庫，倉庫が 19 棟 $(6 \%)$, アパートが 3 棟（1\%）であ った。一般家屋はほとんどが木造住宅である。建物の階 層は 2 階が最も多く 225 棟 $(73 \%)$, 次いで 1 階が 79 棟 (25\%)，3 階が 1 棟 $(0.3 \%)$ であった。また, 倒壊に より不明なものも 5 棟 $(2 \%)$ あった。屋根についてはト タンが 176 棟 $(57 \%)$, 瓦が 69 棟 $(22 \%)$, スレートが 30 棟 $(10 \%)$, 茅莫 1 棟 $(0.3 \%)$, その他が 34 棟 (11\%) であった。

\section{2 調査結果}

建物被害調査の結果を Table 1 に示す。被害ランクの 内訳は，被害の大きい方から A ランクが 7 棟, B ランク が 3 棟, Cランクが 9 棟, そして, D から F ランクがそ れぞれ 9 棟， 83 棟，199棟であった。したがって，建物 が完全に倒壊しているAおよびBランクの建物は全体の 約 $3 \%$ 程度となる。一方, 比較的被害の小さい $\mathrm{E}$ および $\mathrm{F}$ ランクの建物は全体の約 $91 \%$ であり, 調查地域全体とし 
ては外観上の被害が比較的小さかったといえる。

$\mathrm{A} ， \mathrm{~B}$ ランクの建物はすべて木造で，その用途は一般 家屋が 9 棟, 店舗が 1 棟, 階層は 2 階が 3 棟, 1 階が 2 棟，不明が 5 棟，屋根はトタンが 3 棟，瓦が 3 棟，不明 が 4 棟であった。これらの結果から，深刻な被害と被災 した建物の階層や屋根材との間に有意な相関は見いだせ ない。

被害調查の結果を地図上にプロットしたものが Fig. 3 である。この図から桃生総合支所周辺の 3 力所とその南 西側および桃生郵便局の北側（図中の破線で囲まれた場 所）において局所的に深刻な被害が生じていることがわ かる。建物被害を評価するうえで，建築年代を考慮す心゙ きであるが，今回は正確な資料が得られなかったことか ら考慮されていない。しかし，著者らが一棟一棟目視で 調査した範囲において，建築年代が空間的に明らかに偏 っているという事実は確認できなかった。建築年代の偏 りが小さいと考えれば，建物被害の原因は局所的な地震 動の増幅である可能性が高い。なお， A ランクから F ランクに分類された建物の例を一部付録に掲載した。

\section{4. 微動 $\mathrm{H} / \mathrm{V}$}

建物被害と地盤の振動特性との比較を行うため，建物 の被害調査を実施した地域と同じ範囲で常時微動観測を 実施した。観測点は東浜街道沿いに約 $100 \mathrm{~m}$ 間隔で行い, 被害の大きい場所はやや詳細に観測を実施した。Fig. 4 に観測点位置を示す。図中には観測点番号が 55 まで存 在するが，番号に飛びがあり実際の観測点数は 46 点で ある。これは観測を予定していたが，事情により観測が できなかった場合があるためである。各観測点において $\mathrm{NS}, \mathrm{EW}, \mathrm{UD}$ の 3 成分単点観測を行った。観測時間は 5 分間, サンプリング周波数は $100 \mathrm{~Hz}$ である。観測には東 京測振製のサーボ型速度計（VSE-15D）とデータ収録装 置（SPC-51）を用いた。微動 $\mathrm{H} / \mathrm{V}$ の算出は，まず，観 測された 5 分間の微動データから振幅が安定した 20 秒 間のデータを 5 区間選び，それぞれに対してフーリエ変 換とバンド幅 $0.25 \mathrm{~Hz}$ の Parzen Windowによる平滑化 を行う。その後, 水平動, 上下動のスペクトル比（微動 $\mathrm{H} / \mathrm{V})$ を求める。このとき水平動のスペクトルは NS 成 分と $\mathrm{EW}$ 成分の二乗和の平方根とした。最後に 5 区間の 微動 $\mathrm{H} / \mathrm{V}$ の平均を求め, その地点の微動 $\mathrm{H} / \mathrm{V}$ とする。 このような手順で算出した微動 $\mathrm{H} / \mathrm{V}$ を Fig. 5 に示す。 Fig.5 には 5 区間それぞれの微動 H/V をグレーで，平均 した微動 $\mathrm{H} / \mathrm{V}$ を太線で表示している。微動 H/V の卓越 振動数に着目すると, 調查地域の卓越振動数は $1 \mathrm{~Hz}$ から $4 \mathrm{~Hz}$ 程度まで場所によって異なる值をとっている。そし て，観測領域の北部と南部の観測点（例えば 01, 02, 03 や $34,35,37)$ では $1 \mathrm{~Hz}$ 程度に卓越振動数を持ち, 中心 部である桃生総合支所付近の観測点では $2 \mathrm{~Hz}$ 以上に卓
越振動数を持つ地点が多いことがわかる（例えば 16,17 , 18 など）。ただし，桃生総合支所付近では 17 や 54 のよ うに $1 \mathrm{~Hz}$ 付近にもピークを持つ地点も場合もある。Fig. 4 の各観測点は, 卓越振動数に応じて色づけをしている。 微動 $\mathrm{H} / \mathrm{V}$ の卓越振動数の決定においてピークが複数存 在する場合は，振幅值が最大となる周波数を卓越振動数 とした。

\section{5．建物被害と地盤特性の関係}

\section{1 微地形区分データとの比較}

ここではまず，既往のデータである微地形区分と建物 被害との関係を検討する。2 章でも触れたように $250 \mathrm{~m}$ メッシュ微地形区分（若松ほか，2004）によれば，今回 の調査地域は中心部が後背湿地で, 北部と南部が自然堤 メッシュ微地形区分（若松ほか，2004）によれば，今回 の調査地域は中心部が後背湿地で，北部と南部が自然堤 防に分類されている（Fig. 1b）。松岡ほか（2005）によ る微地形区分ごとの深さ $30 \mathrm{~m}$ までの地盤の平均 $\mathrm{S}$ 波速 度（AVS30）の平均值を見ると, 自然堤防では $200 \mathrm{~m} / \mathrm{s}$ 程度，後背湿地で $150 \mathrm{~m} / \mathrm{s}$ 程度となっている。これを藤 本・翠川（2006）の手法により最大速度振幅に対する地 盤増幅度に変換するとそれぞれ 2.55 倍, 3.26 倍程度と なり, 後背湿地の増幅率がやや大きい值となる。これは, 自然堤防に分類されている北部と南部の被害が小さく, 後背湿地に分類されている中心部の被害が大きいという 傾向と概略は一致している。しかし, 今回の地震では後 背湿地に分類されている地域の中で被害に大きな差が生 じている。このような被害の様子を微地形区分だけで説 明することは難しい。

\section{2 微動 $H / V$ との比較}

Fig. 6 は, 被害が A および B ランクであった建物の位 置と, 微動 H/V の卓越振動数を示したものである。

被害の小さかった北部および南部では，ほとんどの観 測点が $1 \mathrm{~Hz}$ 付近に明瞭な卓越振動数を持っている。一 方，被害の大きかった中心部では，多くの観測点の卓越 振動数が $2 \mathrm{~Hz}$ 以上であった。スペクトルの形状も，北部 や南部のように明瞭なピークが存在するのではなく，複 数のピークを持つ場合や, $2 \mathrm{~Hz}$ から $4 \mathrm{~Hz}$ 付近まで卓越振 動数に幅を持つものが多い。このことは，北部や南部に 比べ中心部では地盤構造が複雑であることを示唆してい る。建物被害との関係を見ると, 特に卓越振動数が $2.5 \mathrm{~Hz}$ 以上の地点と被害が $\mathrm{A} ， \mathrm{~B}$ ランクの地点とが非常によく 一致していることがわかる。この関係は桃生郵便局北側 に 1 軒だけ存在する A ランクの地点でも同様であり, 建 物被害と微動 $\mathrm{H} / \mathrm{V}$ の卓越振動数との相関が極めて高い ことが明らかになった。しかし，卓越振動数が $2.5 \mathrm{~Hz}$ 以 上の地点すべてにおいて深刻な被害が生じているわけで 

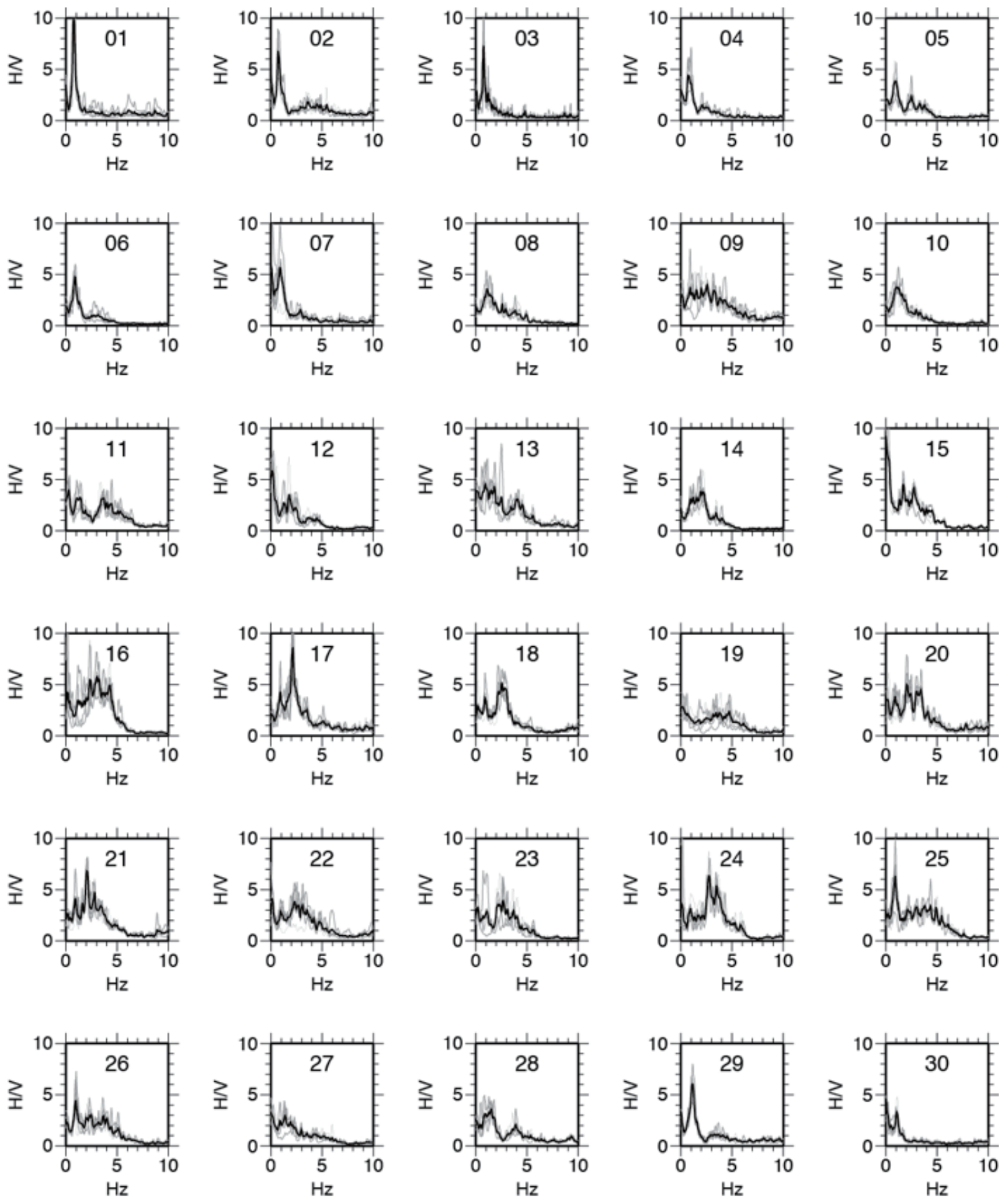

Fig. 5. H/V spectrum ration observed at each observation point. Number indicated in the each graph area represents the observation point number. 

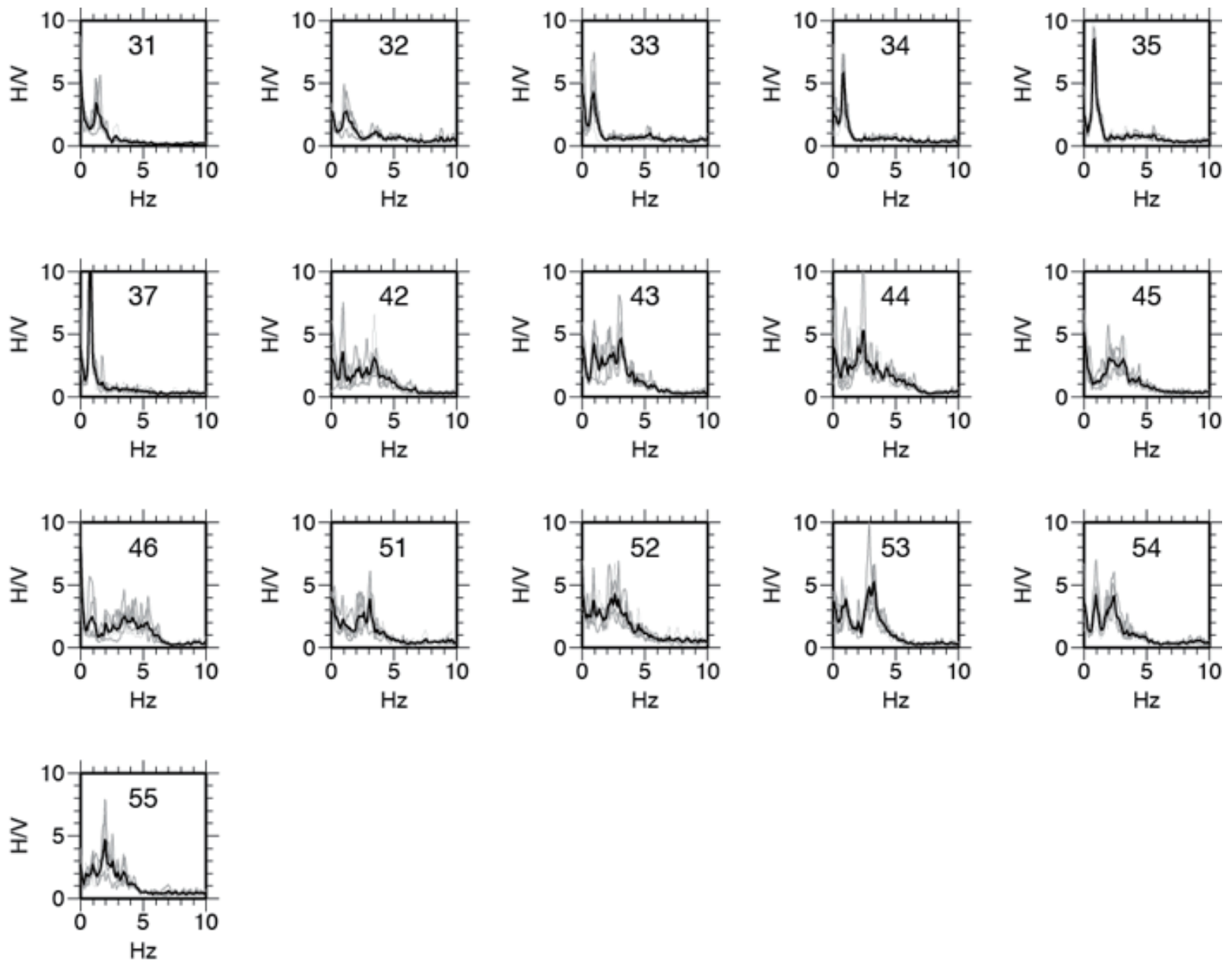

Fig. 5. (continue)

はない。

今回の地震では， $1 \mathrm{~Hz}$ 以上の卓越周波数を持った観測 データが多く，構造物に大きな被害をもたらすと言われ る $0.5 \mathrm{~Hz}$ から $1 \mathrm{~Hz}$ の周波数成分 (1から 2 秒の周期成分) と一致しないため，建物被害が小さかったという指摘が ある（例えば，飯塚ほか，2011）。今回の地震動が $1 \mathrm{~Hz}$ 以上の比較的高周波数成分が卓越していたために, $2.5 \mathrm{~Hz}$ 以上の卓越周波数を持つ地点で共振現象により地 震動が大きく増幅した可能性が高い。一方，構造物に影 響を及ぼしやすい $1 \mathrm{~Hz}$ 付近に卓越周波数を有している 地点において深刻な被害が生じていない。

\section{6. まとめ}

2011 年東北地方太平洋沖地震において局所的な建物 被害を受けた石巻市桃生町において, 詳細な建物被害調 査と常時微動観測を実施した。その結果, 以下のことが 明らかになった。

1）被害ランク A または B という深刻な被害を受けた
建物は，調査した建物（310 棟）のうち約 $3 \%$ 程度 であった。

2）被害ランク $\mathrm{A}, \mathrm{B}$ の建物は, 桃生総合支所周辺の 3 カ所とその南西側および桃生郵便局北側の 5 力所 だけに存在しており, 非常に限られた場所で深刻な 被害が生じている。

3）被害ランク A, B の地点では, 微動 $\mathrm{H} / \mathrm{V}$ の卓越振 動数が $2.5 \mathrm{~Hz}$ 以上であった。

4）被害が小さかった地点の微動 $\mathrm{H} / \mathrm{V}$ は $1 \mathrm{~Hz}$ 付近に明 瞭な卓越周波数を有していた。

今回の地震では $1 \mathrm{~Hz}$ 以上の短周期成分が卓越してい る強震観測記録が多く得られている。微動 H/V の卓越振 動数が $2.5 \mathrm{~Hz}$ 以上の地点で被害が大きかったことは，こ の短周期成分を多く含む地震動と表層地盤との共振現象 が原因である可能性が高い。また, 地震動の継続時間が 非常に長かったことも相乗的な効果をもたらしていると 考えられる。一方で卓越振動数が $2.5 \mathrm{~Hz}$ 以上の地点がす べて深刻な被害を受けているわけではないこと, そして, 一般に構造物に影響を及ぼしやすい $1 \mathrm{~Hz}$ 付近に卓越振 動数をもつ地盤での被害が小さかったことについては今 
後詳細な検討を行う必要がある。

前述のとおり，2011 年 10 月から桃生町内の 2 ケ所に おいて余震観測を実施している。余震観測データを用い てこれらの課題について検討を行う予定である。

\section{謝 辞}

本研究の一部は首都大学東京傾斜的研究費の補助を 受けて実施しました。図面の一部に国土地理院電子国土 Web システムのものを利用させて頂きました。また，一 部の図面は General Mapping Tools（Wessel and Smith, 1998）を用いて作成しました。現地調査では石巻市桃生 総合支所，石巻市立桃生新田保育所の皆様には多大なご 協力を頂きました。また，首都大学東京大学院都市環境 科学研究科都市基盤環境学域須貝健吾君，石山智久君， 横野真也君には微動観測で協力して頂きました。匿名の 查読者には有益なご指摘を頂きました。ここに記して感 謝申し上げます。

\section{参 考 文 献}

飯塚裕暁・林 祐樹・境 有紀・神田和紘（2011）：2011 年東 北地方太平洋沖地震で発生した地震動と建築被害（その 1 ) 強震記録と観測点周辺の被害, 日本地震工学会・大会 2011 梗概集, 40-41.

藤本一雄・翠川三郎 $(2006)$ : 近接観測点ペアの強震記録に基 づく地盤増幅度と地盤の平均 $\mathrm{S}$ 波速度の関係，日本地震工 学会論文集，6(1).

松岡昌志・若松加寿江・藤本一雄・翠川三郎（2005）：日本全 国地形・地盤分類メッシュマップを利用した地盤の平均 $\mathrm{S}$ 波速度分布の推定，土木学会論文集，794/I-72, 239-251. 桃生町編纂委員会 (1990)：桃生町史 第 3 巻 自然民俗編, pp. 660.

八幡 啓・山崎晴雄（2008）: 2007 年能登半島地震・新潟県中 越沖地震および 2008 年岩手・宮城内陸地震における詳細建 物被害分布と地形・地質的要因, 日本地理学会発表要旨集, 74, 133.

若松加寿江・松岡昌志・久保純子・長谷川浩一・杉浦正美 （2004）: 日本全国地形・地盤分類メッシュマップの構築, 土木学会論文集，759/I-67，213-232.

Wessel, P., and Smith, W. H. F. (1998): New improved version of Generic Mapping Tools released, Eos Trans. AGU, 79, 579 .

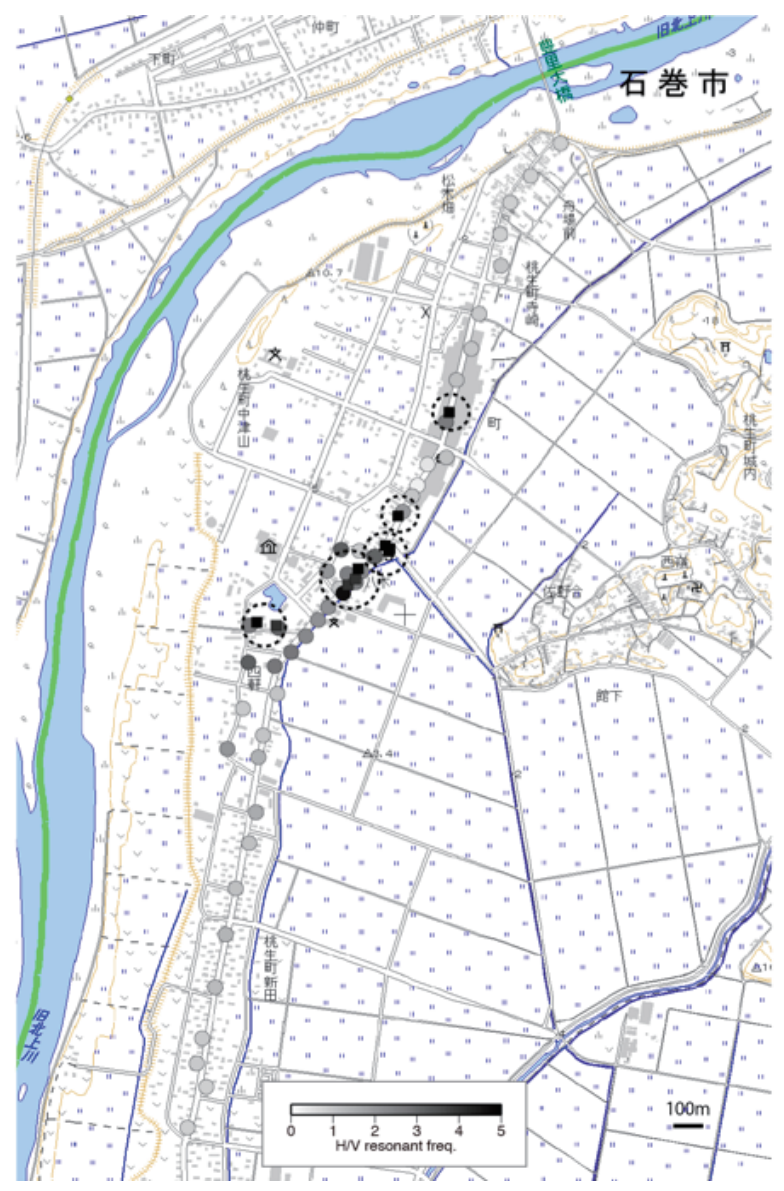

Fig. 6. Map view of damaged houses ranked A and B (squares in dashed circles) with results of microtremor measurements (circles). The color of circles represents resonant frequency of $\mathrm{H} / \mathrm{V}$ spectrum ratio. 
付録. 被害ランクごとの建物例
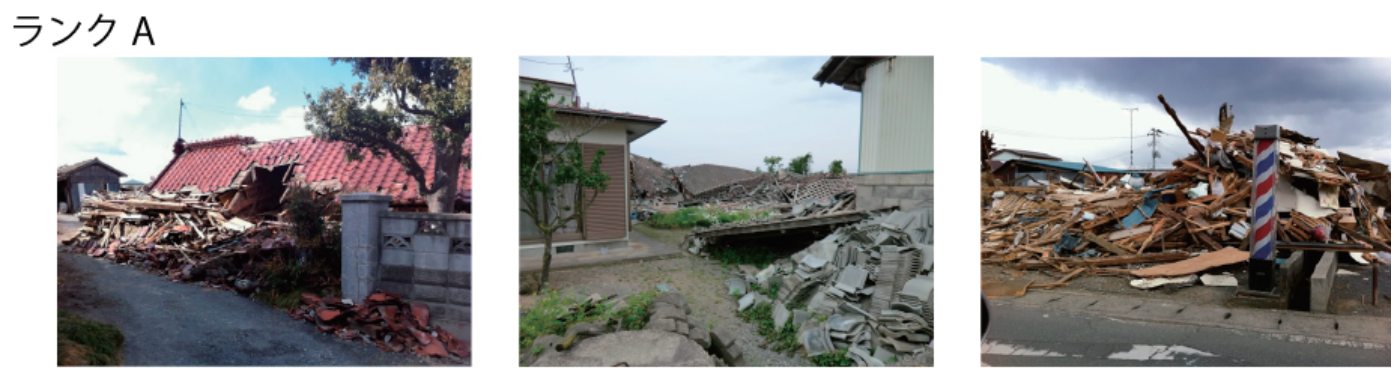

ランク B
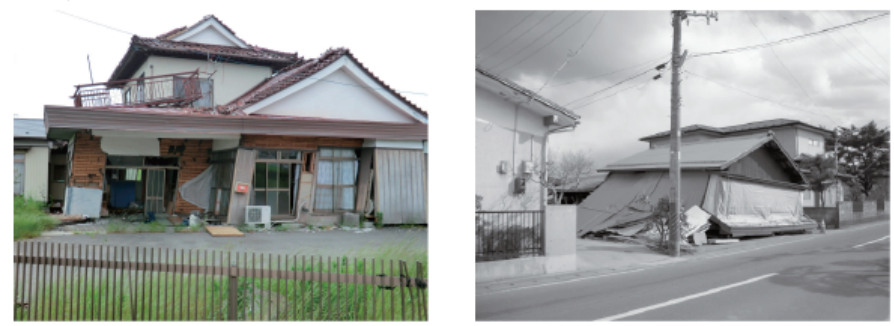

ランク C
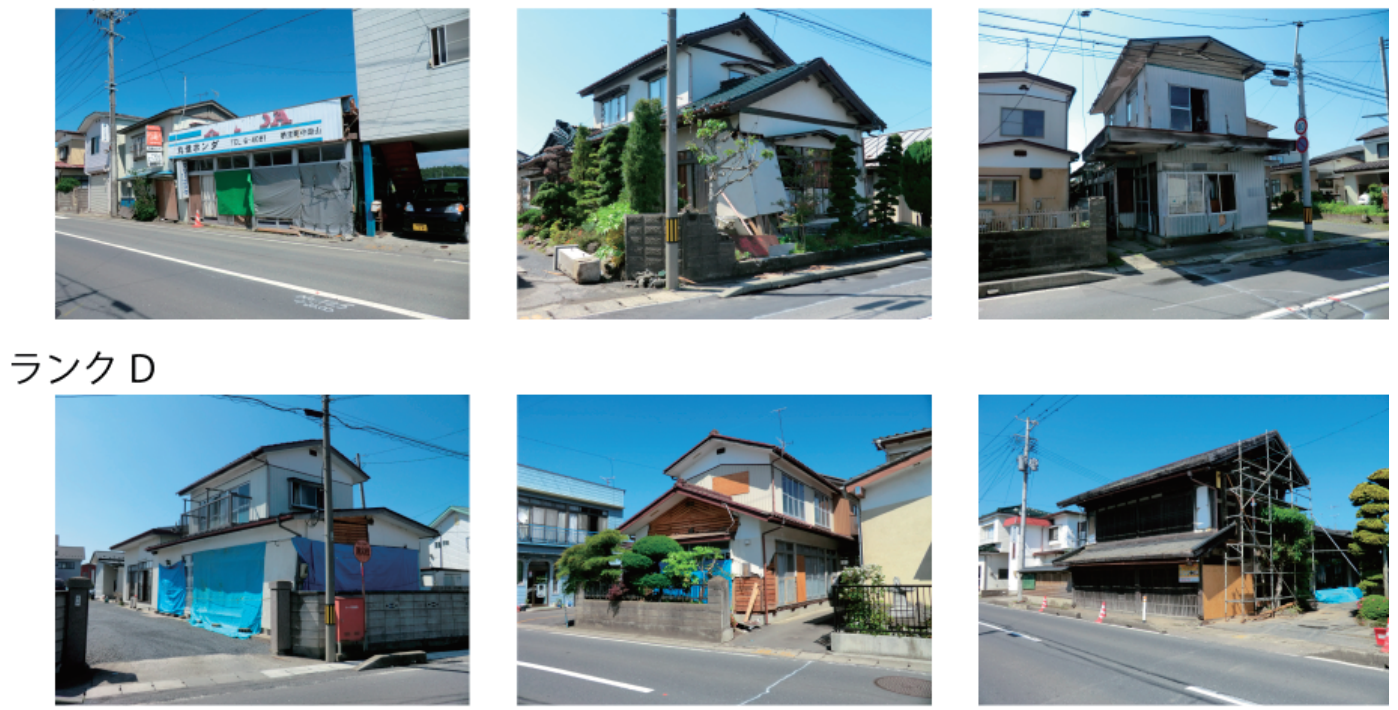

ランク $\mathrm{E}$
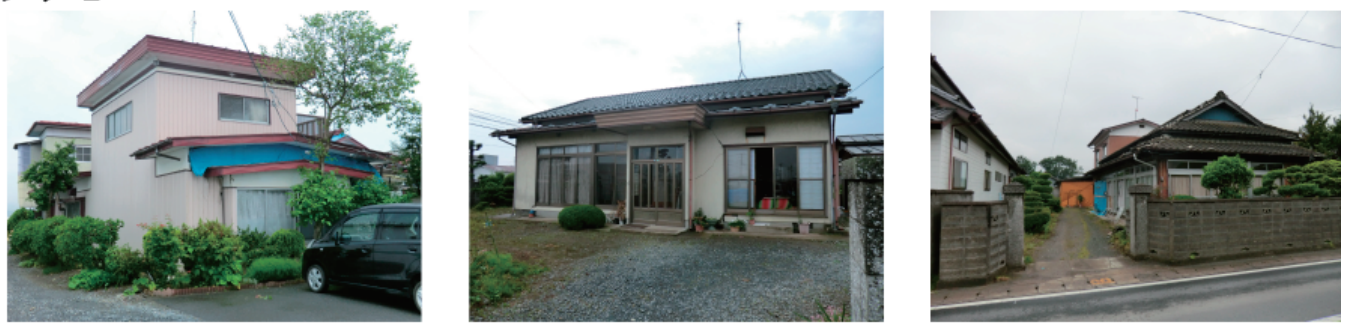

ランク $F$
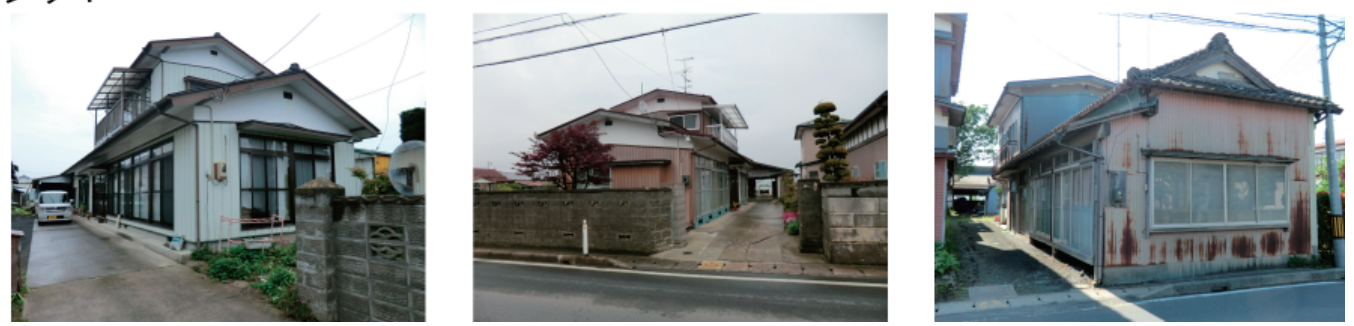


\title{
Relation between local house damages during the 2011 off the Pacific coast of Tohoku earthquake and microtremor H/V at Monou-cho, Japan
}

\author{
Yoshiya Oda* and Yutaro Toda*
}

\begin{abstract}
The 2011 off the Pacific coast Tohoku Earthquake triggered powerful tsunami that caused major damage of the coast of from Kanto through Tohoku. However, house damages caused by strong ground motion of this earthquake was not so heavy relatively to its magnitude and seismic intensities. Although house damages was not so heavy on the whole, there are houses seriously damaged by the earthquake in Monou-Cho, Ishinomaki City, Miyagi Prefecture, Japan. The locations of damaged houses are limited in Monou-Cho. To figure out the cause of such local earthquake damage, we conducted investigation of house damages and microtremor measurements three months after the earthquake. We classified each house into 6 damage ranks according to the house damage investigation. The number of seriously damaged houses classified to rank A and B is 10 (approx. 3\%) and its location is limited around the City Hall of Monou-Cho. Microtremor measurements was conducted at 46 points and predominant frequency of $\mathrm{H} / \mathrm{V}$ spectrum ratio varied from 1 to $4 \mathrm{~Hz}$. Locations of seriously damaged houses classified to A and B correspond to points with predominant frequency over $2.5 \mathrm{~Hz}$. Housed would collapsed because of resonance phenomenon between strong motion and surface geology with predominant frequency over $2.5 \mathrm{~Hz}$.
\end{abstract}

Keywords: 2011 off the Pacific of Tohoku Earthquake, Monou-cho, local house damage, microtremor H/V, resonance phenomenon

Manuscript received December 9, 2011; Accepted February 7, 2012.

* Tokyo Metropolitan University Civil and Environmental Engineering.

1-1, Minam-osawa, Hachioji, Tokyo 192-0397, Japan
A part of this paper was presented at the 125th SEGJ fall conference, 2011. 